\title{
A Study of the Determinants of Corporate Environmental Disclosure in MENA Emerging Markets
}

\author{
Mejda Mahmoudi Akrout ${ }^{1, *}$ and Hakim Ben Othman ${ }^{2, \#}$ \\ ${ }^{1}$ Member of LIGUE-ISCAE, PhD. Student, at ISCAE, University of Manouba, Tunisia \\ ${ }^{2}$ Maître de Conférences Agrégé of Accounting, and Finance, in Charge of the Accounting, Major at Tunis \\ Business School, University, of Tunis, Senior Member of LIGUE-ISCAE, Univeristy of Manouba, Tunisia
}

\begin{abstract}
The purpose of this study is to investigate environmental disclosure determinants in Arab Middle Eastern and North African (MENA) companies. In this regard, we investigate factors which are specific to this context. We include the 'business culture' variable inherited from former colonisers and main economic partners and the 'state ownership' and 'family ownership' variables. In addition, we consider "Country's Internet Penetration" as a new explanatory variable which is expected to influence environmental disclosure on the web site. Using a sample of 153 web sites of listed companies, findings show a negative and significant relationship between environmental disclosure and 'family ownership'. Moreover, consistent with prior work, the level of environmental disclosure is substantially affected by company size and performance.
\end{abstract}

Keywords: Environmental disclosure, determinants, Arab Middle Eastern and North African (MENA), web sites.

\section{INTRODUCTION}

Societal expectations of corporate performance have changed considerably over the last two decades and different stakeholder groups are putting great pressure on corporations to become more environmentally responsible. As a result, an increasing number of companies are now making environmental disclosures.

Numerous articles have investigated factors that impact the extent of firm's environmental disclosure (e.g. Coween et al. 1987; Patten 1991 in the United States; Huse et al. 1997, and Cormier \& Magnan, 2004 in Europe). More recently, the literature has given growing attention to exploring environmental disclosure in Asian emerging markets over the last few years (Wong et al. 2001; Xiao et al. 2005in Hong Kong; Haniffa and Cooke, 2005 in Malaysia; Zengal et al. 2010 in China). However, a few studies have focused on corporate environmental disclosure in Arab countries (Al-Bastiki 1997 in Bahrain; Abu-Baker 2000 in Jordan; Naser et al. 2006 in Qatar; Rizk et al. 2008 in Egypt). These studies are restricted to the investigation of one country and examine only annual reports as the primary corporate communication medium.

However, internet reporting is a recent but fastgrowing phenomenon (Oyelere et al., 2003). Many companies around the word have launched internet

\footnotetext{
${ }^{*}$ Address corresponding to this author at the P.O. Box 72; Gabes, Tunisia; Tel: +21699631527; E-mail: Majouda_mahmoudi@yahoo.fr

"Co-Author E-mail: hakim.bo@planet.tn
}

reporting, which is used to communicate financial and non-financial information. A number of studies have documented well the practices of internet reporting, although most of these studies are concentrated on the financial information and investigated developed countries. Similarly, studies that have investigated the issue of environmental disclosure via the web are essentially descriptive and give an overview of the environmental disclosure practices on the Internet as in developed countries (Aly et al. 2009; Lodhia S, 2006, etc.) rather than in emerging market countries (Dutta et al. 2009, etc.).

The literature is relatively silent regarding corporate environmental reporting in Middle Eastern and North African (henceforth MENA) Arab emerging markets. Very few or almost no studies have focused on the determinant of environmental disclosure in MENA emerging markets. Moreover, in this context, we observe a large number of firms operating in polluting sectors, such as petrochemical, energy, food, etc. These companies have an important role in national economies but can also have significant environmental impacts.

The purpose of this paper is to address this gap in the literature by examining environmental practices and determinants of MENA polluting firms on their web sites.

In this regard, we will try to explore country-specific variables in the MENA region, such as "business culture" and "ownership concentration". It is remarkable that business culture in MENA countries is inherited from former colonisers and their main economic 
partners with the Anglo-American developed countries or with France. This variable is expected to influence corporate environmental disclosure. Indeed, as a specificity of companies in the MENA region, we note the concentration of ownership that is characterized by the presence of "Family and State Ownership". Moreover, we will integrate "Country's Internet Penetration" which is expected to influence environmental disclosure on company web sites. This variable has not been used in prior environmental disclosure studies. We believe that this variable is an important factor in the web disclosure decisions of a firm.

This study is of value in that it enlarges the scope of previous studies through its inclusion of other regions of the world. It contributes to the environmental accounting literature by bringing insights from the MENA region, where little is known about its environmental accounting features, despite, the fact that, this region forms an important part of the current and future global economy. However, while previous studies test for company characteristic as company size, leverage and profitability, we add three more variables specific to the MENA region, namely business culture, family ownership and state ownership. This research, then, extends prior work on corporate environmental disclosure by expanding its scope to web-based environmental information in emerging markets where most of studies have investigated environmental reporting practices through print media. Finally, this study helps to explain Arab MENA corporate behavior in terms of environmental disclosure and has significant practical implications for a number of decision makers especially regulators in the MENA region.

In this study, we investigate the web sites of 153 companies from Arab MENA countries. The results indicate that the majority of companies in the sample had a separate section for environmental issues on their web site. However, the disclosures were found to be general statements indicating company support for environmental protection. Multivariate analysis shows that family ownership presents a significant negative association with the web sites environmental disclosure levels. However, company size and profitability are more important variables in voluntary disclosure of environmental information.

The remainder of this paper is organized as follows. Section 2 provides a brief outline of the MENA region emerging economies, Section 3 presents prior literature and develops the hypotheses for the study. The research design is described in Section 4. In Section 5, we present the results and discussion. Section 6 concludes this paper.

\section{MENAREGION PROFILE}

The Arab MENA states mentioned in this study have become more and more integrated into the global economy. These countries have been moving steadily away from central economic planning to market economies and open door policies. Striving to participate in the global economy, Arab MENA countries are taking majors steps in enhancing the private sector's role in the economy, developing foreign business and economic liberation. A number of Arab countries, such as Egypt and Jordan have undertaken IMF and Word Bank development programs for guidance on economic liberation. Similarly, most MENA countries are now members of the World Trade Organisation (WTO) and some of them (e.g., Tunisia, Morocco and Egypt) have concluded free trade agreements with the European Union. (Ben Othman and Zeghal, 2010).

Most of the Arab countries in this study have at one time been under Western powers control. As is the case of many countries that were at one time part of the British or French Empire, these countries found that when they achieved their independence they had a professional accounting body and company legislation based on the British (or French) models (Briston, 1990). In Egypt, for example, as a result of the British colonial influence from 1882 to 1956, the training of accountants, the organisation of the accounting profession, the law regulating companies, disclosure standards and the financial reporting practices were all based on those of the UK (Samuels and Oliga, 1982). Moreover, international financial reporting standards (IFRS) are required in most MENA emerging markets. In Bahrain, Oman and Kuwait, IASs have been adopted as national standards (IASB, 2005), while, the rest of the MENA countries (Tunisia, Morocco, Saudi Arabia et al.) are converging to IFRS (Pacter report, 2008) as a way to attract international investors.

In addition, despite moves towards market liberalization, the state's role in the business environment of these countries is very significant (Lopez-Claros and Schwab, 2005). Indeed, as in most emerging economies, ownership in MENA emerging markets is highly concentrated. More specifically, ownership in Arab MENA companies is strongly 
concentrated with a significant proportion held by the state and families (Omran, 2007).

Privatization in the MENA region has been progressing more slowly than other developing countries in Latin America and Asia. This might be due to the fact that privatization in Asia is a relatively old phenomenon compared to the MENA region where privatization on a large scale is relatively recent. Hence, the progress of privatization to date is not yet considered by investors as a credible signal of government commitment, especially in institutionally weaker environments, such as the MENA region (Ben Naceur et al. 2009).

Using a sample of more than 300 representative Arab firms (Oman, Egypt, Jordan and Tunisia), Omran (2008) demonstrated that Egypt remains the country with the largest presence of government ownership at 34 percent. On the other hand, Jordan and Oman emerge as the countries with the highest private ownership. These countries have more than 80 percent of firm ownership in the hands of private institutions and individuals. Tunisia comes is as the country with the largest foreign participation in firm ownership at 18 percent - surely facilitated by the free trade agreement with the EU - and also appears to be the one with the least participation by local individuals.

Indeed, Al-Moatez and Lakhel (2008), investigate a sample of 48 Saudi companies including manufacturing firms with a percentage of 47.9 percent, followed by the service industry with 25percent. Descriptive statistics show that the Saudi firms are mostly held by families (the mean percentage of family ownership in Saudi Arabia is 22.2 percent) and the government (state ownership is present on average at about 10 percent).

\section{BACKGROUND AND DEVELOPMENT OF HYPOTHESES}

Corporate environmental reporting has been mainly a phenomenon of developed countries and, consequently, most corporate environmental reporting studies have been confined to developed countries.

A handful of studies have concentrated on the newly industrialized countries, such as Hong Kong, China, Korea and Malaysia. In addition, a majority of corporate environmental reporting has primarily focused on conventional print media, especially annual reports, as a disclosure medium (Lodhia, 2005). However, web-based environmental communication studies are a relatively new addition to the environmental communication literature.

\subsection{Prior Research}

The "earlier" literature on web based environmental communication (such as Craven and Otsmani 1999; Williams and Pei 2000 as cited by Lodhia (2006) indicated that larger companies and those operating in developed countries are more likely to use the web for environmental communication. More recent literature has focused specifically on larger companies operating in the developed world. These studies include: Patten (2002); Allam and Lymer (2002); Cormier and Magnan (2003) and Andrew (2003). The common finding in these studies is that companies are not extensively utilising the web for environmental communication.

Allam and Lymer (2002) examined the type of information available on the internet for 50 companies from fives countries, namely, the USA, UK, Canada, Australia and Hong Kong. Findings indicate that only 36 percent of the US companies' web sites had environmental information.

KPMG's (2002) survey, found that environmental reporting still continues to be the highest in countries, such as the USA, Japan, Germany and UK and in industries, such as chemicals, pharmaceuticals and automotive.

Adams and Frost (2004) did a comprehensive study of web-based environmental communication in Australia, the United Kingdom (UK) and Germany. They analyzed websites, sent surveys to corporate managers and also held interviews at specific companies. Their findings suggested that there was limited use of websites for environmental communication. The authors also reveal that the main purpose of developing corporate web sites was to raise corporate awareness and to improve corporate image rather than to report ethical and environmental issues and use web based technologies to engage stakeholders.

Lodhia (2006) examined the web-based environmental communication practices of companies in an environmentally sensitive industry, the Australian Minerals Industry. The companies' websites (fourteen companies) were analysed over two different time periods, July and November, 2003. The findings of this research indicated that the potential of the web was not extensively utilised by companies for environmental communication. 
In emerging markets, Dutta and Bose (2008) investigated the utilization of corporate websites for communicating corporate environmental information by the listed companies of Bangladesh. For that purpose, corporate websites of 104 companies for the period of three months (August 1, 2007 to November 3, 2007) were analyzed. This study shows that web-based corporate environmental reporting in Bangladesh is still in its infancy, as the level of environmental disclosures on corporate websites is very low.

Al-Arussi et al. (2009) examined whether the voluntary environmental disclosures through the internet can be explained by the same determinants as in conventional reporting. Six hypotheses were tested using data collected from 201 Malaysian listed companies for the financial year 2005. The results indicate that the level of technology, ethnicity of CEO and firm size are determinants of internet environmental disclosures.

Focusing on the MENA region. Aly et al. (2009) analysed the potential factors that may affect the level of corporate internet reporting by Egyptian listed companies. This study highlighted that 56 percent of Egyptian companies report a significant portion of information on their web sites. In addition, the results indicate that profitability, foreign listing and industry type are the determinants of the amount and presentation formatting of information disclosed on Egyptian companies' web sites.

In Jordan, Al-Haybat (2011) seeks to explain corporate online reporting by using companies' characteristics as explanatory factors for any variations in disclosure. The finding showed that variations in corporate online reporting were associated with size, performance, foreign ownership and online company familiarity.

Most of the prior research on web-based environmental communication is descriptive, merely focusing on information content on websites and comparing this between developed countries. Few studies are investigating the web's environmental disclosure in developing countries. Mostly, these studies were conducted in the context of newly industrialized Asian countries such as Malaysia and Singapore. The current research surveys the environmental disclosure practices and determinants via the web sites of companies operating in the Arab MENA region in an attempt to fill a gap in the current literature.

\subsection{Development of Hypotheses}

Based on prior research, the studies which investigated the factors that may influence the amount of corporate environmental disclosed on web sites have analyzed the same variables as the annual reports. Consequently, in this study we will use the same factors that may explain the corporate environmental disclosure on the web sites. At the same time, previous research shows many determinants of environmental disclosure, such as firm size, debt, profitability, etc. However, the influence of these variables was different between countries. In this regard, and in order to understand the environmental practices and determinants for companies of the Arab MENA region, we will try to investigate factors which are specific to this context. The environmental disclosure behavior within MENA emerging markets has been inherited from former colonisers with whom they still maintain significant economic and business relations. Consequently, we include a new variable: the "business culture" inherited from former colonisers and main economic partners. Indeed, unlike developed countries where ownership is widely spread among different shareholders, ownership is highly concentrated in the MENA region. Therefore, we will test the impact of "state ownership" and "family ownership" on environmental disclosure. Then, we will add a new explanatory variables "Country's Internet Penetration" which is expected to influence environmental disclosure on the web site.

\subsubsection{Business Culture}

MENA countries have been market by either a strong tie with the UK and the USA or with France. Gulf States and Jordan maintain privileged economic relations with developed Anglo-American countries specifically with the USA and the UK. However, former French colonies in the MENA region (e.g.; Morocco and Tunisia) have privileged economic relations with developed continental European countries, specifically with France. Therefore, a business culture inherited from former colonisers and main economic partners should be an important determinant of the level of environmental corporate disclosure in the MENA region. In this regard, Saudagaran and Biddle (1992) reported that the disclosure requirement and expectations in Anglo-American developed countries are higher than in continental European countries. Indeed, Ben Othman and Zeghal (2010) examined transparency and disclosure determinants for MENA companies. Using a sample of 216 annual reports, the 
results show that MENA companies from countries having historical links with Britain have substantially higher transparency and disclosure scores than MENA companies in former French colonies. With this in mind, we present the following hypotheses.

H1: MENA companies in former British colonies or with strong economic ties with the Anglo-American countries are expected to communicate higher levels of environmental disclosure via web sites than MENA companies from former French colonies.

\subsubsection{Ownership Structure}

Despite the growing position of capital markets in the MENA emerging economies and the adoption of privatization programs, ownership is highly concentrated with a significant proportion held by the state and families (Omran, 2007). The descriptive statistics show that in the food and pharmaceutical sectors "family ownership" is dominant whereas "state ownership" is dominant in all other sectors.

Family-owned companies prevail on the MENA capital markets and the predominance of family members or close relatives suggests an important role in the executive position within the company (Miteva, 2007). These stakeholders can use their power by requesting information directly from company management. In this case, the possibility of forcing management to voluntarily disclose environmental information on their web sites is remote. Therefore, we propose:

H2: There is a negative association between family ownership and environmental disclosure.

Furthermore, government ownership is a main feature in the MENA region. The government is expected to show that it acts for the benefit of society. A company with high government ownership is expected to observe environmental protection principals in order to be seen as a good example for other companies totally owned by the private sector.

Naser et al. (2006) reported a positive but insignificant association between the extent of environmental disclosure and government ownership in Qatar.

Accordingly, we hypothesize:

H3: Firms with government ownership are more likely to disclose environmental information.

\subsubsection{Internet Penetration}

Debrency et al. (2002) demonstrated a positive relationship between the level of Internet use in the country and the extent of information disclosure by companies via their websites. Similarly, firms will likely have higher environmental disclosure if they believe that there is a large Internet audience amongst their domestic stakeholders.

The use of the Internet varies widely between MENA countries, the highest level of Internet penetration is 81.6 percent in Qatar. Egypt shows the lowest level (26.7 percent) (ICT, indicators database, 2010).

In countries where there is heavy penetration of Internet usage, it is expected that many companies will adopt voluntary disclosure of environmental information via the internet. Therefore, it can be hypothesised that:

H4: The level of Internet environmental disclosure is positively associated with the country's internet penetration.

\subsubsection{Control Variables}

In the following, we discuss hypotheses related to control variables.

\subsubsection{Firm Size}

Prior studies (e.g. Cormier and Magnam, 2003) found a positive relationship between company size and the level of environmental disclosure in a number of countries.

As such, larger companies are inclined to report more frequent and more accurate environmental information to ensure a positive social image in the information disseminated to the public and delivered to investors. Accordingly, we expect that larger firms are more likely to disclose environmental information through their web sites than smaller firms.

\subsubsection{Leverage}

Companies' investors and lenders rely on financial statements for the evaluation of a firm's financial standing and credit rating. Therefore, managers are inclined to increase disclosure to reduce agency costs between insiders and creditors.

Empirical literature provides mixed results. Cormier and Magnan (2002) and Brammer and Pavelin (2006) demonstrated a negative relationship between environmental disclosure and leverage. However, 
Roberts (1992) and Naser et al. (2006) reported a positive association.

This study investigates companies which operate in polluting sectors. These firms are more likely to be punished. With this in mind, the bankers and lenders will pay more attention to these companies' communication about corporate environmental responsibility. Consequently, the polluting companies will prefer to report more environmental information if they have more debt. Therefore, we propose that firms with higher debt are more likely to disclose environmental information.

\subsubsection{Profitability}

Based on signaling theory and agency theory, it can be argued that because of the separation between the manager and the owners of companies and the difficulties that investors face in directly observing the extent and the quality of managers' efforts on their behalf, investors will depend on reports of managers' performance to monitor their investments. Managers of companies with better performance than others wish to distinguish their performance through a process of voluntary disclosures such as corporate environmental information.

While Cormier and Magnan (2004) documented a weak association between corporate social disclosure and profitability, Zheng et al. (2009) found a positive relationship for Chinese companies. In this study, we expect a positive association between profitability and the extent of environmental disclosure.

\section{METHODOLOGY}

\subsection{Data and Sample Selection}

We collected listed companies from the Arab MENA region that operate in polluting sectors. These companies were selected because they are more sensitive towards environmental issues and they normally invest much more in environment protection than those from other industries (Salomone et al. 2001; Moneva et al. 2000; Gamble et al.1995; Barth et al. 1994). KPMG (2002) found that sectors showing the most activity in environmental reporting were those in high risk areas such as chemicals, pharmaceuticals and automotive. Based on prior research. The polluting sectors selected in this study are: pharmaceutical (Adams et al. 2000), energy (Tilt, 2001; Anderson et al. 1998; Barth et al. 1994), chemical (Adams et al. 2000; Anderson et al. 1998; Barth et al. 1994), mining
(Anderson et al. 1998), transportation (Bartoloméo, 2000; Barth et al. 1994), and food (Barth et al. 1994).

The sample construction starts with collecting lists of companies operating in polluting sectors from web sites of financial markets in the MENA region as well as from the web site www.gulfbase.com which specializes in financial and stock market information of companies in GCC countries. We downloaded the web sites of these companies in December 2010. For that, we used the software "HTTrack web site" which allows the aspiration of the entire contents of the websites. From this sample, we removed companies which do not have web sites or those having inaccessible web sites. This left us with a sample of 153 companies. Distribution of the sample between different sectors is shown in Table 1.

Table 1: Distribution of Sample Companies

\begin{tabular}{|c|c|c|}
\hline Sectors & Number of companies & Percentage \\
\hline \hline Mining & 45 & $29.41 \%$ \\
\hline Food & 39 & $25.49 \%$ \\
\hline Chemical & 36 & $23.52 \%$ \\
\hline Energy & 12 & $7.8 \%$ \\
\hline Transportation & 11 & $7.1 \%$ \\
\hline Pharmaceutical & 10 & $6.68 \%$ \\
\hline Total & 153 & $100 \%$ \\
\hline
\end{tabular}

\subsection{Empirical Model}

In this study, we attempt to explain environmental disclosure (score) factors through web sites for Arab MENA companies. In the first model, we tested determinants of environmental communication via web sites. This model integrates "Business Culture", "Family and State Ownership" as specific variables of the MENA region and "Internet Penetration" in order to investigate factors that influence environmental disclosure via web sites. We added in Model 2 MENA country dummies as control variables.

Model 1:

SCORE $=\alpha_{0}+\alpha_{1}$ BUS-CUL ${ }_{i}+\alpha_{2}$ FAM-OWN ${ }_{i}+\alpha_{3}$ GOV OWN $_{i}+\alpha_{4}$ INT-PEN $_{i}+\alpha_{5}$ SIZE $_{i}+\alpha_{6}$ LEV $_{i}+\quad \alpha_{7}$ PROF $_{i}+e_{i}$

Model 2

SCORE $=\alpha_{0}+\alpha_{1}$ BUS-CUL ${ }_{i}+\alpha_{2}$ FAM-OWN ${ }_{i}+\alpha_{3}$ GOV-

$\mathrm{OWN}_{i}+\alpha_{4}$ INT$-P E N_{i}+\alpha_{5}$ SIZE $_{i}+\alpha_{6}$ LEV $_{i}+$

$\alpha_{7}$ PROF $_{i}+$ COUNTRY DUMMIES $+e_{i}$ 
Where

SCORE:: the environmental disclosure rating of firm $\mathrm{i}$.

BUS-CUL: is a dummy variable. It takes a value of one if the firm $i$ is located in a country which has strong economic ties with United Kingdom or United States, zero if the firm $i$ is located in a French business culture MENA country.

FAM-OWN: family ownership of firm I, measured by the percentage of capital held by family (year ended 2010).

GOV-OWN: government ownership of firm i, measured by the percentage of capital held by the state (year ended 2010).

INT-PEN: Internet Penetration of firm i.

SIZE: size of firm i, measured by the "log total assets" (year ended 2010).

$L_{E V}$ : leverage of firm $\mathrm{i}$, measured by "debt to assets ratio" (year ended 2010).

PROF profitability of firm i. we use the ROA as a measure of the profitability (year ended 2010).

\subsection{Environmental Disclosure Measurement: SCORE}

In order to measure a firm's environmental disclosure, we based it on the Environmental Indicators developed within the frame work of the Global Reporting Initiative (GRI) (the last version entitled "G3.1" and published in March 23, 2011). The GRI provides guidelines to firms in reporting on economic, environmental and social aspects of their activities, products and services and is the internationally accepted standard for TBL reporting (Colman, 2004 and 2005; Hopkins, 2004).

Through comparison of the items in the GRI as well as from the investigation of web sites of the sample, a list was developed, which is more closer to the context of study (see Appendix A).

The approach to scoring items is dichotomous in that an item scores one if disclosed and zero if it is not. Data for all 33 items that make up the environmental disclosure score were directly and manually extracted from the web sites for the year ended 2010.

The scores for each item are added and equally weighted to derive a final score for each company.
The score for each company $j$ is calculated as follows:

SCORE $=\frac{\sum_{\mathrm{i}-1}^{\mathrm{N}} \mathrm{X}_{\mathrm{ij}}}{\mathrm{N}}$

Where $\mathrm{N}$ is the total number of items expected to be disclosed for firm $i$.

$X i j$ is equal to 1 if item $j$ is disclosed for firm $i$, and 0 if not disclosed.

\subsection{Measurement of Independent Variables}

*BUS-CULi: Business culture is a dummy variable that distinguishes Arab MENA countries influenced by British business culture from those influenced by French business culture. It takes a value of one if the firm $i$ is located in a country which has strong economic ties with the United Kingdom or United States, zero if the firm $i$ is located in a French business culture MENA country.

*FAM-OWNi and GOV-OWNi: family ownership and government ownership of firm i, to measure these variables, we use:

- $\quad$ Percentage of capital held by family (year ended 2010) for family ownership.

- Percentage of capital held by the state (year ended 2010) for government ownership.

*SIZEi: size of firm i. Prior studies shown that there is a positive relationship between size and environmental disclosure (Patten, 1992; Cormier and Magnan 1999; Neu \& et al. 1998; Leuz and Verrecchia, 2000 ; etc). This variable was derived through several proxy measures (the turnover, the number of employees, total assets, etc). In this research, the size will be measured by the "log total assets" (year ended 2010)

*LEVi: leverage of firm i. in this study the measure used to present leverage is "debt to assets ratio" (year ended 2010).

*PROFi: profitability of firm i. several ratios were used to assess the influence of profitability on environmental disclosure. In this investigation, we use the ROA as a measure of the profitability (year ended 2010)

*INT-PENi: Internet Penetration of firm i. The rate of Internet penetration for each country in this study will 
Table 2: Distribution of Environmental Score for MENA Emerging Markets

\begin{tabular}{|c|c|c|c|c|c|}
\hline Country & $\mathbf{N}$ & Mean & St. dev & Min & Max \\
\hline Bahrain & 3 & .0606 & .1049 & 0 & .182 \\
\hline Egypt & 16 & .1270 & .1470 & 0 & .484 \\
\hline UAE & 22 & .1240 & .1305 & 0 & .394 \\
\hline Jordan & 14 & .1126 & .1622 & 0 & .575 \\
\hline Kuwait & 14 & .0367 & .0906 & 0 & .303 \\
\hline Morocco & 10 & .1031 & .1262 & 0 & .364 \\
\hline Oman & 18 & .0474 & .0634 & 0 & .212 \\
\hline Qatar & 7 & .0779 & .1062 & 0 & .272 \\
\hline SaudiArabia & 41 & .0977 & .1163 & 0 & .364 \\
\hline Tunisia & 8 & .0912 & .0961 & 0 & .364 \\
\hline
\end{tabular}

be collected from statistics compiled by the ITU (International Telecommunication World/ICT indicators database).

\section{RESULTS AND DISCUSSION}

\subsection{Descriptive Statistics and Univariate Analysis}

As shown in Table 2, we note that environmental scores are quite low. The mean environmental score is between (0.1240) for companies in the UAE and (0.0367) for companies in Kuwait. The investigation of the sample shows that the majority of companies in this study had a separate section for environmental issues on their website. However, the disclosures were found to be general statements indicating company support for environmental protection and describing projects undertaken to reduce pollution and save energy and resources. These findings are in line with results obtained in previous studies (Allam and Lymer, 2002; Adams and Frost, 2004; Lodhia, 2006) and suggested that there was limited use of websites for environmental communication.

Table 3 provides the univariate difference of the environmental scores between companies pertaining to Anglo-Saxon and French business cultures. The t-test and Wilcoxon Mann Withney for equal variances (we have a small sample size, so we cannot assume normality) indicate that the environmental score does not differ much by inherited business culture ( $p$ value $>0.05$ ).

In the developing of hypotheses, we expected that the correlation between the level of environmental disclosure of a company in the MENA region and family ownership would be negative. This correlation is positive with the presence of government ownership and "Country's Internet Penetration" as a new explanatory variable. However, the findings show that all the correlation coefficients in Table $\mathbf{4}$ are not significant.

\subsection{Multivariate Analysis}

Table 5 presents regression results of the environmental score on test and control variables based on the sample of MENA companies.

The variance inflation factors (VIF) were calculated to assess the extent of any multicollinearity problem. All VIF factors are less than 5 (mean=1.12) indicating that there is no serious problem of collinearity. The Breusch-Pagan test statistic indicates the existence of heteroscedasticity in the models. However, we treated this problem of heteroscedasticity with the test of White via Stata software. The Fisher statistic is significant at a

Table 3: Univariate Analysis Difference of Environmental Scores Between Companies Pertaining to Anglo-American and French Business Cultures

\begin{tabular}{|c|c|c|c|c|c|c|}
\hline $\begin{array}{c}\text { Dependant } \\
\text { variable }\end{array}$ & $\begin{array}{c}\text { Business } \\
\text { culture }\end{array}$ & $\mathbf{N}$ & Mean & Std. Dev. & $\begin{array}{c}\text { t-statistic } \\
(\mathbf{p} \text {-value })\end{array}$ & $\begin{array}{c}\text { z-statistic } \\
(\mathbf{p} \text {-value) }\end{array}$ \\
\hline \hline SCORE & French & 18 & .0923 & .1113 & 0.2436 & 0.129 \\
\hline & Anglo-American & 135 & .0921 & .1210 & $(0.8078)$ & $(0.8976)$ \\
\hline
\end{tabular}

Notes: SCORE: the environmental disclosure rating of firm i. Business culture. It takes a value of one if the firm $i$ is located in a country which has strong economic ties with the United Kingdom or United States, zero if the firm $i$ is located in a French business culture MENA country (Tunisia and Morocco). 
Table 4: Correlation Results Between Environmental Scores and Family Ownership, Government Ownership and Internet Penetration

\begin{tabular}{|c|c|c|c|c|}
\hline & N & FAM-OWN & GOV-OWN & INT-PEN \\
\hline \hline SCORE & 153 & -0.1065 & 0.0908 & -0.005 \\
& & $(0.190)$ & $(0.264)$ & $(0.946)$ \\
\hline
\end{tabular}

Notes: SCORE: the environmental disclosure rating of firm i. FAM-OWN: family ownership of firm I, measured by the percentage of capital held by family (year ended 2010). GOV-OWN: government ownership of firm i, measured by the percentage of capital held by the State (year ended 2010). INT-PEN: Internet Penetration of firm

Table 5: Regression of Environmental Score on Test and Control Variables Based on the Sample of MENA Companies

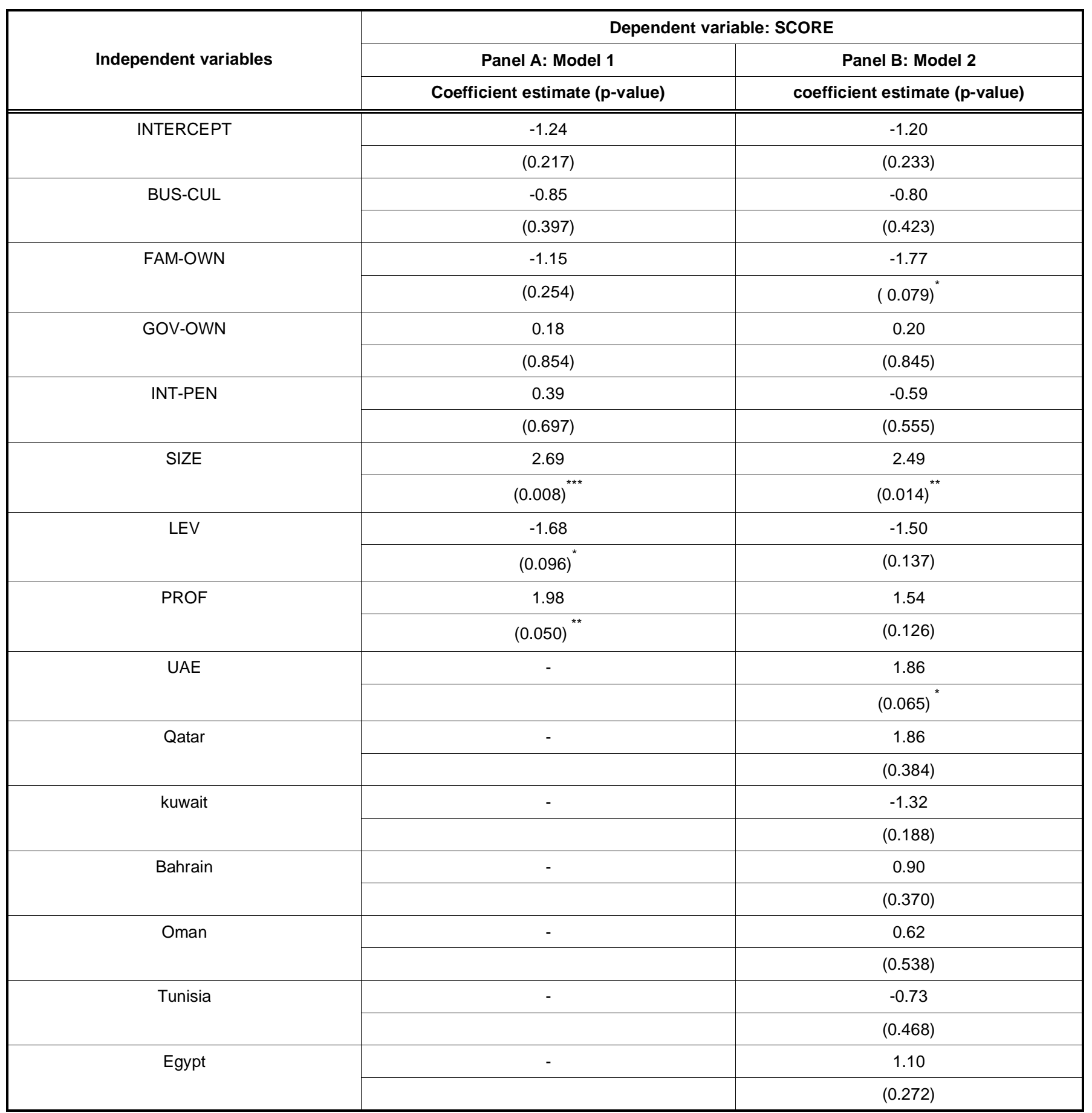


(Table 5). Continued.

\begin{tabular}{|c|c|c|}
\hline \multirow{3}{*}{ Independent variables } & \multicolumn{2}{|c|}{ Dependent variable: SCORE } \\
\hline & Panel A: Model 1 & Panel B: Model 2 \\
\hline & Coefficient estimate (p-value) & coefficient estimate ( $p$-value) \\
\hline \multirow[t]{2}{*}{ Morocco } & - & 0.42 \\
\hline & & $(0.678)$ \\
\hline \multirow{2}{*}{$\begin{array}{c}\text { F statistic } \\
\text { Prob }>F\end{array}$} & 1.94 & 1.65 \\
\hline & $(0.0479)^{* *}$ & $(0.0585)^{*}$ \\
\hline R square & 0.14 & 0.17 \\
\hline
\end{tabular}

Notes:

Model 1

SCORE $=\alpha_{0}+\alpha_{1}$ BUS-CUL $_{i}+\alpha_{2}$ FAM-OWN ${ }_{i}+\alpha_{3}$ GOV-OWN ${ }_{i}+\alpha_{4} I N T-P E N_{i}+\alpha_{5} S_{I Z E_{i}}+\alpha_{6} L_{E V}+\alpha_{7} P R O F+e_{i}$

Model 2

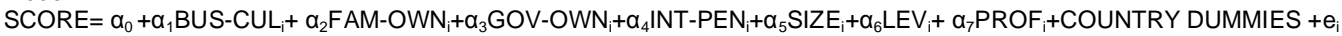

SCORE: the environmental disclosure rating of firm iBUS-CUL: Business culture. It takes a value of one if the firm $i$ is located in a country which has strong economic ties with the United Kingdom or United States, zero if the firm $i$ is located in a French business culture MENA country(Tunisia and Morocco); FAM-OWN: family ownership of firm I, measured by the percentage of capital held by family (year ended 2010); GOV-OWN: government ownership of firm i, measured by the percentage of capital held by the state (year ended 2010); INT-PEN: Internet Penetration of firm i.; SIZE: firmsize = log total assets ;LEV: leverage =debt to assets ratio; PROF: profitability $=$ ROA.

In Model 2, Saudi Arabia was considered as a country reference due to the large number of Saudi companies.

Indicate two-tailed statistical significance at $1 \%, 5 \%$ and $10 \%$ levels.

level of 5 percent (F-statistic of 1.94) in model 1 and at 10 percent in the second model (F-statistic of 1.65).

Table 5 indicates that no significant relation between the business culture variable and the extent of environmental disclosure exists. This finding is different from results obtained by Ben Othman and Zeghal (2010) and which indicate a positive and significant influence of the business culture milieu on the transparency and disclosure levels for MENA emerging market companies.

Concerning the ownership structure, Table $\mathbf{5}$ presents results which are consistent with our hypotheses in Model 2. This variable is significant at a level of 10 percent when we added in the second model "MENA country dummies" as control variables (t-statistic of -1.77). While the relationship between environmental disclosure and government ownership is not significant in the two models. Similarly, internet penetration seems to have no effect on environmental disclosure.

Moreover, consistent with prior research, findings support the empirical evidence that size and profitability are important variables in voluntary disclosure of information related to social and environmental activities (Patten, 2002; Allam and Lymer, 2002; Cormier and Magnan, 2003 and Andrew, 2003). The coefficients obtained for the size and performance variables are positive and statistically significant at a level of 1 percent for size (t-statistic of 2.69) and at a level of 5 percent for performance (t-statistic of -1.68) in Model 1. Size variables have less of an influence on the level of environmental disclosure when we added them into Model 2 MENA country dummies as control variables. In addition, we find a negative and significant relationship between environmental disclosure and leverage in Model 1 at a level of 10 percent. However, this variable has no more significance when we added it into Model 2 of the MENA country dummy variables.

Results report that the influence of the majority of variables is not statistically significant, as shown by their coefficients. These findings may be due to several factors. First, There are no standards and regulations that determine the content of environmental disclosure and require companies to communicate environmental information. Also, the MENA region consists of emerging markets and therefore the demand for environmental information by investors is relatively low. Besides, the vast majority of MENA listed companies have concentrated ownership mainly through family ownership which reduces the level of environmental disclosure for outsiders.

\section{CONCLUSION}

The purpose of this paper is to investigate the determinants of environmental disclosures via the web sites of Arab MENA companies. In this regard, we included the "business culture" variable inherited from 
former colonisers and main economics partners. Moreover, unlike developed countries where ownership is widely spread among different shareholders, ownership is highly concentrated in the MENA region. Therefore, we tested the impact of "state ownership" and "family ownership" on environmental disclosure. Furthermore, we added "Country's Internet Penetration" as a new explanatory variable which was expected to influence environmental disclosure on the web site.

We collected 153 web sites of listed companies. We downloaded the web sites of these companies in December 2010. The analysis of the sample shows that the majority of companies in this study provide a separate section for environmental issues on their website. However, disclosure is found to be made up of general statements indicating company support for environmental protection and the environmental scores are quite low. These results can be explained by the fact that the majority of MENA listed companies have concentrated ownership mainly through family ownership which leads to a significant negative association with the web sites' environmental information disclosure levels.

Among all the investigating variables, company size has the most significant impact. It is shown in this study that the larger the company is, the more they take environment problems into account, and the better the environmental information disclosed. A company's profitability also has a great impact on disclosure. One possible explanation is that polluting companies willingly unveil some environmental accounting information to show that they have corporate environmental responsibility. These results are in line with those of previous studies on environmental communication disclosure mentioned above.

The dominance and influence of accounting systems inherited from former colonisers, on accounting practices in the Arab MENA region has created a very narrow view of the role of accounting as primarily an obligation to report financial information. Managers do not pay much attention to the information needs of other users, such as the government, workers or society at large.

There are some limitations inherent to the exploratory nature of this study. First, more consistency would be provided by analysing information on web sites at different period rather than being analysed at one particular time (Lodhia, 2006) and results would be more conclusive if more companies had been included in the sample. Second, in regard to internal validity, the list of items on environmental activities to compute the environmental disclosure index might not be exhaustive. Furthermore, the sample in this study was taken from the polluting sectors. Consequently, the results may have limited external validity beyond the industry settings of the study. Despite these limitations, this research contribute to the understanding of environmental disclosure via web sites in MENA emerging markets. As the growth in the internet continues, we expect more companies will be creating web sites within the next few years.

In relation to practice, this study highlights the use of the web for environmental communication and suggests that companies are not fully utilising this potential for environmental communication. It is suggested that policy makers such as regulators and environmental associations could play a key role in providing an impetus to companies to move beyond merely using websites for organizing environmental information and to utilise the "full" communication potential of the web.

Furthermore, the Web has emerged and speedily spread over the years, and while it has extensive usage for e-commerce activities, corporate communication is another area where it could be successfully utilized. Continuous communication, use of presentation features (such as audio and video clips, webcasts, and even video conferencing), greater interactivity and personalization are envisaged for webbased environmental communication in the future. Increased academic research in this area and development of methods that could capture the dynamic nature of change of information on websites would also be beneficial.

\section{APPENDIX A. ENVIRONMENTAL DISCLOSURE ITEMS LIST}

\section{List of Items}

\section{Aspect: Materials}

Consumption of raw materials

Recycling

\section{Aspect: Energy}

Direct energy consumption by primary energy source.

Indirect energy consumption by primary source. 
Energy saved due to conservation and efficiency improvements.

- Initiatives to provide energy-efficient or renewable energy-based products and service

- Initiatives to reduce energy consumption

\section{Aspect: Water}

- $\quad$ Consumption of water(total water consumption)

- Water sources significantly affected by withdrawal of water.

Total volume of water recycled and reused

\section{Aspect: Biodiversity}

Location and size of land owned, leased, managed in, or adjacent to, protected areas and areas of high biodiversity

Description of significant impacts of activities, products, and services on biodiversity

Habitats protected or restored.

Strategies, current actions, and future plans for managing impacts on biodiversity and environment.

Number of IUCN Red List species in areas affected by operations,

\section{Aspect: Emissions, Effluents, and Waste}

Total direct and indirect greenhouse gas emissions

Other relevant indirect greenhouse gas emissions by weight.

Initiatives to reduce greenhouse gas emissions

Emissions of ozone-depleting substances by weight.

NOx, SOx, and other significant air emissions

Reduction of water, air and desert discharges

Reduction of total weight of waste

Total number and volume of significant spills.

Secure management of waste

Identity, size, protected status, and biodiversity value of water bodies and related habitats significantly affected by the reporting organization's discharges of water and runoff.

\section{Aspect: Products and Services}

Initiatives to mitigate environmental impacts of products and services, and extent of impact mitigation.

- $\quad$ Percentage of products sold and their packaging materials that are reclaimed by category.

\section{Aspect: Compliance}

Monetary value of significant for noncompliance with environmental laws and regulations.

\section{Aspect: Transport}

reduction environmental impacts of transporting products and other goods and materials used for the organization's operations, and transporting members of the workforce.

\section{Aspect: Overall}

Total environmental protection expenditures and investments by type.

Develop structures with respect to the environment

- Pollution control due to the company's business

Compliance of the company with the standards for pollution

\section{REFERENCES}

Al-Basteki, H. 1995. "The Voluntary Adoption of International Accounting Standards by Bahraini Corporations". Advances in International Accounting 8: 47-64.

Abu-Baker, N and K. Naser. 2000. "Empirical Evidence on Corporate Social Disclosure (CSD) Practices in Jordan". International Journal of Commerce and Management 10: 18. http://dx.doi.org/10.1108/eb047406

Adams, C. A and N. Kuasirikum. 2000. "A Comparative Analysis of Corporate Reporting on Ethical Issues by UK and German Chemical and Pharmaceutical Companies". The European Accounting Review 9(1): 53-79. http://dx.doi.org/10.1080/096381800407941

Adams, C and G. Frost. 2004. "The Development of Corporate WebSites and Implications for Ethical, Social and Environmental Reporting Through These Media". The Institute of Chartered Accounting of Scotland, Edinburg.

Al-Htaybat, K. 2011. "Corporate Online Reporting in 2010 : A Case Study in Jordan". Journal of Financial Reporting and Accounting 9(1): 5-26.

http://dx.doi.org/10.1108/19852511111139778

Al-Arussi, A. S., M. H Selamet and M. Hanefah. 2009. "Determinants of Financial and Environmental Disclosures Through the Internet by Malaysian Companies". Asian Review of Accounting 17(1): 59-76. http://dx.doi.org/10.1108/13217340910956513 
Al-Moataz, E and F. Lakhal. 2008. "Corporate Governance Disclosures and Corporate Governance Mechanisms: The Case of Saudi Listed Companies". working paper.

Aly, D., J. Simon and K. Hussainey. 2009. "Determinants of Corporate Internet Reporting: Evidence From Egypt". Managerial Auditing Journal 25(2): 182-202. http://dx.doi.org/10.1108/02686901011008972

Anderson, A., N. Elias and D. Zéghal. 1998. "Environmental Management and Reporting". Ed.CGA. Canada.

Andrew, J. 2003. "Corporate Governance, the Environment, and the Internet". Electronic Green Journal 19, http://egj.lib.uidaho. edu/egj19/andrew1.html.

Barth, M. E., M. McNichols and P. Wilson. 1997. "Factors Influencing Firm's Disclosures About Environmental Liabilities". Review in Accounting Studies 2: 35-65. http://dx.doi.org/10.1023/A:1018321610509

Bartolomeo, M. 2000. "Environmental Management Accounting in Europe: Current Practice and Future Potential". European Accounting Review 9(1): 31-53. http://dx.doi.org/10.1080/096381800407932

Ben Othman, H. and D. Zeghal. 2010. "Investigating Transparency and Disclosure Determinants at Firm-level in MENA Emerging Markets". International Journal Accounting, Auditing and Performance Evaluation 6(4): 368-36. http://dx.doi.org/10.1504/IJAAPE.2010.036152

Ben Naceur, S., N. Boubakri and S. Ghazouani. 2009. "Privatization and Financial Market Development in Emerging Countries: A Comparative Study". Working paper.

Brammer, J. S and P. Stephen. 2006. "Corporate Reputation and Social Performance: The Importance of Fit". Journal of Management Studies, Blackwell Publishing 43(3): 435-455. http://dx.doi.org/10.1111/j.1467-6486.2006.00597.x

Briston, R. J. 1990. "Accounting in Developing Countries: Indonesia and the Solomon Islands as Case Studies for Regional Corporation". Research in Third World Accounting 1: 195216.

Colman, R. 2004. "Satisfied Stakeholders". CMA Management 78(1): 5-22.

Colman, R. 2005. "Corporate Social Responsibility: Where Do We Really Stand". CMA Management 78(9): 28-33.

Cormier, D. and M. Magnan. 2003. "Environmental Reporting Management: A European Perspective". Journal of Accounting and Public Policy 22(1): 43-62. http://dx.doi.org/10.1016/S0278-4254(02)00085-6

Cowen, S. S., L. B. Ferreri and L. D. Parker. 1987. "The Impact of Corporate Characteristics on Social Responsibility Disclosure: A typology and Frequency-Based Analysis". Accounting, Organizations and society: 111-122. http://dx.doi.org/10.1016/0361-3682(87)90001-8

Craven, B. N. and C. L. Marston. 1999. "Financial Reporting on the Internet by leading UK Companies". The European Accounting Review 8(2): 321-333. http://dx.doi.org/10.1080/096381899336069

Debreceny, R., G. L. Gray and A. Rahman. 2002. "The Determinants of Internet Financial Reporting". Journal of Accounting and Public Policy 21(4-5): 371-394. http://dx.doi.org/10.1016/S0278-4254(02)00067-4

Dutta, P. and S. Bose. 2008. "Corporate Environmental Reporting on the Internet in Bangladesh: An Exploratory Study". International Review of Business Research 4(3): 138-150.

Gamble, G., K. Hsu., C. Jackson and C. Tollerson. 1996. "Environmental Disclosures in Annual Reports: An International Perspective". International Journal of Accounting 31(3): 293-331. http://dx.doi.org/10.1016/S0020-7063(96)90022-9

Haniffa, R. M. and T. Cooke. 2005. "The Impact of Culture and Governance on Corporate Social Reporting". Journal of Accounting and Public Policy 24: 391-430. http://dx.doi.org/10.1016/j.jaccpubpol.2005.06.001
Halme, M. and M. Huse. 1997. "The Influence of Corporate Governance, Industry and Country Factors on Environmental Reporting". Scandinavian Journal of Management 13: 137157.

http://dx.doi.org/10.1016/S0956-5221(97)00002-X

Hopkins, M. 2004. "Corporate Social Responsibility". An Issues Paper, Policy Integration Department World Commission on the Social Dimension of Globalisation International Labour Office.

Leuz, C. and R. Verrecchia. 2000. "The Economic Consequences of Increased Disclosure". Journal of Accounting Research 38(supplement 2000): 91-124. http://dx.doi.org/10.2307/2672910

Lodhia, S. 2006. "The World Wide Web and Its Potential for Corporate Environmental Communication: A Study into Present Practices in the Australian Mineral Industry". The International Journal of Digital Accounting Research 6(11): 65-94.

Lopez-Claros, A. and K. Schwab. 2005. "The Arab world Competitiveness Report". Hampshire, UK: Palgrave Macmillan, World Economic Forum.

Lymer, A. M. 1997." The Use of the Internet for Corporate ReportingA Discussion of the Issues and Survey of Current Usage in the UK". Journal of Financial Information systems.

Monova, J. M. and F. Lena. 2000. "Environmental Disclosures in the Annual Reports of Large Size Companies in Spain". European Accounting Review 9(1): 7-29. http://dx.doi.org/10.1080/096381800407923

Mitiva, E. 2007. "Corporate Governance in the Middle East and North Africa". The Executive. (November- December):38-40,

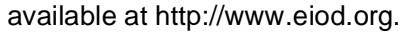

Naser, K., A. Al-Hussaini., D. Al-Kwari and R. Nuseibeh. 2006. "Determinants of Corporate Social Disclosure in Developing Countries: The Case of Qatar". Advances in International Accounting 19: 1-23. http://dx.doi.org/10.1016/S0897-3660(06)19001-7

Neu, D., H. Warsame and K. Pedwell. 1998. "Managing Public Impressions: Environmental Disclosures in Annual Reports". Accounting, Organizations and Society 23(April): 265-283. http://dx.doi.org/10.1016/S0361-3682(97)00008-1

Omran, M., A. Bolbol and A. Fatheldin. 2008. "Corporate Governance and Firm Performance in Arab Equity Markets: Does Ownership Concentration Matter?". International Review of Law and Economics 28: 32-45. http://dx.doi.org/10.1016/j.irle.2007.12.001

Oyelere, P., F. Laswad and R. Fisher. 2003. "Determinants of Internet Financial Reporting by New Zealand Companies". Journal of International Financial Management and Accounting 14(1): 26-63. http://dx.doi.org/10.1111/1467-646X.00089

Pacter, P. 2008 Available at http://www.iasplus.com, Deloitte.

Patten, D. M. 1991. "Exposure Legitimacy and Social Disclosure". Journal of Accounting and Public Policy 10: 297-308. http://dx.doi.org/10.1016/0278-4254(91)90003-3

Patten. 2002. "Give or Take on the Internet: An Examination of the Disclosure Practices of Insurance Firm Web Innovators". Journal of Business Ethics 36(3): 247-259. http://dx.doi.org/10.1023/A:1014009229437

Rizk, R., R. Dixon and A. Woodhead. 2008. "Corporate Social and Environmental Reporting: A Survey of Disclosure Practices in Egypt". Social Responsibility Journal 4(3): 306-323. http://dx.doi.org/10.1108/17471110810892839

Roberts, R. 1992. "Determinants of Corporate Social Responsibility Disclosure an Application of Stakeholder Theory". Accounting Organizations and Society 17(6): 595-612. http://dx.doi.org/10.1016/0361-3682(92)90015-K

Salomone. And Galluccio. 2001. "Environmental Issues and Financial Reporting Trends in the Chemical and Oil and Gas Industries". Working paper, $\mathrm{n}^{\circ} 32$. 
Samuel, J. M and J.C. Oliga. 1982. "Accounting Standards in Developing Countries". The International Journal of Accounting 18(1): 69-88.

Saudagaran, S M and G. C. Biddle. 1992. "Financial Disclosure Levels and Foreign Stock ExchangeListing Decisions". Journal of International Financial Management and Accounting 13(3): 106-148. http://dx.doi.org/10.1111/j.1467-646X.1992.tb00025.x

Tilt, C. 2001. "Environmental Disclosure by Australian Companies: What is Happening Outside the Annual Report?". Research paper series.

Williams, S. M. and C. Pei. 1999. "Corporate Social Disclosure by Listed Companies on Their Web Sites: An international comparison". The International Journal of Accounting 34(3): 389-419.

http://dx.doi.org/10.1016/S0020-7063(99)00016-3

Xiao, J. Z., H. Yang and C. W. Chow. 2004. "The Determinants and Characteristics of Voluntary Internet-based Disclosures by Listed Chinese Companies". Journal of Accounting and Public Policy 23: 191. http://dx.doi.org/10.1016/j.jaccpubpol.2004.04.002

Zheng, J., H. Guo and W. Wang. 2009. "The Influence of Financial Factors on Environmental Information Disclosure in Chine Chemical Industry". Xi'an Jiaotong University, PRC, Working paper, available at: http:/ssrn.com/abstract=1305005.

Received on 22-02-2013

Accepted on 29-03-2013

Published on 05-04-2013

DOI: http://dx.doi.org/10.6000/1929-7092.2013.02.5

(C) 2013 Akrout and Othman; Licensee Lifescience Global.

This is an open access article licensed under the terms of the Creative Commons Attribution Non-Commercial License (http://creativecommons.org/licenses/by-nc/3.0/) which permits unrestricted, non-commercial use, distribution and reproduction in any medium, provided the work is properly cited. 